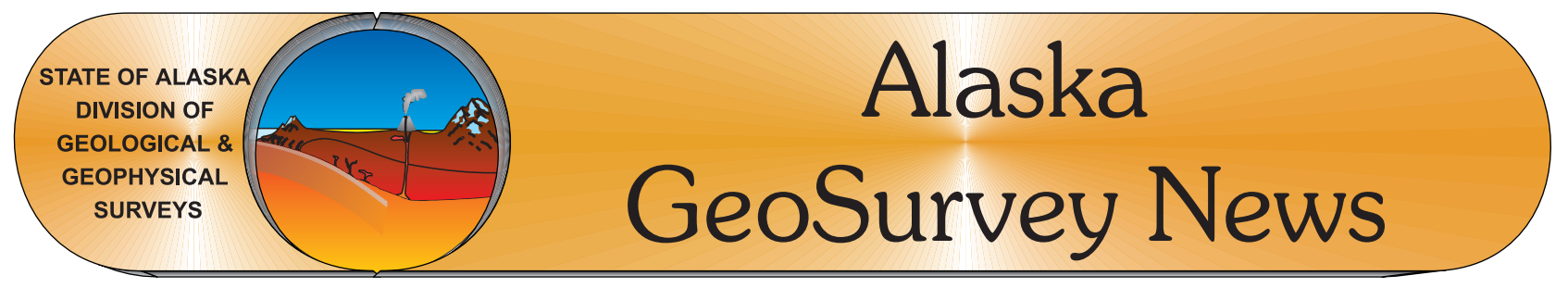

http://wwwdggs.dnr.state.ak.us

Vol. 2, No. 3, October 1998

\title{
GUIDE TO ALASKA GEOLOGIC AND MINERAL INFORMATION
}

\author{
A research tool for geologists, mining companies, miners, educators, and all Alaskans
}

\author{
E. Ellen Daley \\ Alaska Division of Geological \& Geophysical Surveys
}

At the 1998 Fall Alaska Miners Association meeting, the Division of Geological \& Geophysical Surveys (DGGS) will release a new publication designed to help the geologic community and mineral industry find and access information. The Guide to Alaska Geologic and Mineral Information (Information Circular 44) is being produced as part of a program informally called the "Minerals Data at Risk program," a cooperative effort of the United States Geological Survey

(USGS), DGGS, the Bureau of Land Management, and major research libraries and collections in Alaska.

The idea for this Guide originated in discussions between representatives of government agencies, libraries, the mining industry, and members of the public who have an interest in geology and mining. Out of these discussions came the general consensus that generating, preserving, and improving accessibility to information are critical to sound decision making about the use, development, and preservation of Alaska's natural resources-and will become more so in the future. In Fiscal Year 1998, the USGS secured multi-year funding from the U.S. Congress to implement several projects designed to further these goals, including publication of this Guide.

\section{The Guide Is A Tool To Help Locate Information}

The quest for information about the geology of Alaska and issues related to the Alaska mineral industry can be a challenge, especially to persons and companies new to the state. Numerous agencies and institutions are involved in generating and distributing reports, guidelines, and informational fact sheets, and in overseeing land use, mining claims, and permitting of exploration activities. For example, no single

The Guide to Alaska Geologic and Mineral Information is the direct result of

communication and cooperation between state

and federal agencies, and the Alaska geology and

mining community. agency maintains land status or mining claim information for the entire state. This Guide is a tool to help geologists, the minerals industry, students, librarians, agencies, and government representatives identify and locate such technical and non-technical resources.

The primary anticipated users of the Guide are the mining community and geologists from a variety of organizations and agencies. However, much of the information also will be of interest to those involved in oil, gas, and coal exploration, to the larger geology community, and to policymakers and legislators.

Resources for the general geology of Alaska discussed in this Guide include published agency geological and geophysical reports, theses and dissertations, agency and university contacts, and geologic tools such as topographic maps, geologic maps, aerial photos, and remote sensing data.

THE GUIDE CAN HELP YOU FIND . . .

- A library that has USGS, U.S. Bureau of Mines, and DGGS reports you need.

- Locations of current and historic mining claims on specific state and federal lands.

- Agencies that regulate aspects of mineral exploration in Alaska.

- Searchable library catalogs on the Internet.

- Geologic maps for each quadrangle in Alaska.

- Electronic mapping data.

- Where to get permits and permit applications.

- Internet sites for searchable federal and state codes and statutes.

- Electronic geophysical and geochemical data.

- Established sites for recreational mining on state and federal land.

- Newsletters with the latest happenings in the Alaska mining industry. 
"The need for geologic and minerals information has grown tremendously not only in the traditional role of guiding mineral exploration, but in state and federal land management, in protecting the environment, in guiding Native corporations in the use of their land, and in ensuring the economic well being and quality of life of Alaskans and other Americans. ... We need to organize our information better, we need to ensure that it is not lost, and we need to make it more conveniently accessible."

Don Grybeck, U.S. Geological Survey

foreword to Guide to Alaska Geologic and Mineral Information

Research published in scientific journals and books can be identified and located using the bibliographic tools described in the Guide; however, such national and international publications are not specifically addressed.

Sources of information about mineral geology and exploration in Alaska address a broad range of topics in addition to those described above for general geology. Among the range of covered topics are land use and mining claim information sources, regulatory and permitting resources, historical mining data, and environmental and engineering geology resources.

The Guide is 90 pages in length, and is an attractive, userfriendly document. The publication will be available free of charge from the public information offices of most of the participating agencies-

DGGS, the USGS

Earth Science Information Centers, and DNR and BLM public information offices. Reference copies also will be available at libraries and many agency offices in Alaska.

\section{The Guide Also Will Be Available ON The INTERNET}

Preparations are underway to post the information contained in the Guide on the Internet. The amount of information and data available on the Internet is growing daily. This Guide and links from the Guide web site will help identify many useful sites, and more will be added to the web site as they are identified. An Internet site can be updated as addresses and agency roles change, and as new sources of information are identified-without the expense of revising and publishing a new edition of the Guide.
The Internet medium is well suited to Alaska, where the nearest library or agency with the required information may be halfway across the state. With a computer and telephone link, library catalogs can be accessed, data can be downloaded, and information can be transferred almost instantaneously. Many public libraries and other agencies have terminals available for public Internet access, and can assist in finding sites.

\section{The Guide Is A Cooperative Publication}

Although the Guide will be published by DGGS, it truly is the result of interagency cooperation. Librarians from the seven major research collections in Alaska were the principal gatherers of information for the Guide. These include, Cathy Vitale from ARLIS (Alaska Resources Library and Information Service), Barbara Sokolov, recently retired from UAA Consortium Library, Jill Schneider of the USGS Technical Data Unit, Earl Shumaker formerly of UAF Rasmuson Library Government Documents Section, Judie Triplehorn of the UAF Geophysical Institute Library, Martha Murphree of DGGS, and Jane Albrecht of the Bureau of Land Management Juneau Minerals Information Center.

Ellen Daley of DGGS has compiled and edited the Guide and worked with DGGS Geologic Communications personnel on layout and publication. Many other individuals, from agency representatives to Alaska Native regional corporation personnel, have provided information. Don Grybeck of the USGS was instrumental in securing the funding for this Guide from Congress, and Bruce Gamble is the USGS coordinator for this project. $X$ 


\section{Dear Readers:}

In early September, with everyone safely returned from the field, DGGS had its first post field season "gathering of the clan" at our monthly staff meeting. During the meeting each of the project managers reported on the highlights of their team's summer work. I would like to share their successes with you. All are significant. You will be getting the details in the months ahead. I believe that the following summary is indicative of the outstanding professional caliber of the DGGS staff.

- Laurel Burns has overseen the acquisition of approximately 1,250 square miles of airborne geophysical data in the Fortymile mining district. A Request for Proposals to select a contractor to conduct an airborne geophysical survey of a large tract on Prince of Wales Island in southeastern Alaska also has been released.

- Ellen Daley has just about completed a comprehensive guide to sources of data and information relative to Alaska mineral deposits. Printed copies of this guide will be ready for distribution at the annual meeting of the Alaska Miners Association this November. Her work has been sponsored by the USGS.

- Karen Clautice reported that her project team was able to develop a reliable interpretation of the geology in the Upper Chulitna mining district that explains well the area's stratigraphy, structural style, and mineralization. It seems probable that their work, in addition to providing a groundtruth geologic map to help interpret the airborne geophysical data recently acquired for the district, will have important implications for a better understanding of the tectonic history of central Alaska.

- DeAnne Pinney's task force returned to the Petersville mining district in August, after having been forced to retreat in June because of a late snowfall. Their work will provide a geologic map to accompany the airborne geophysical data produced for the Petersville district in 1997.

- Dave LePain led an effort to gather geochemical, stratigraphic, and structural data in the Holitna Basin. The results of this summer's work will guide future efforts to evaluate that area's potential for locally exploitable natural gas resources.

- Jim Clough forged ahead with the DGGS coalbed methane project. Surface samples of coal were collected from the general vicinity of tentatively proposed future drilling sites to test the gas sorption qualities of coal that is being targeted.
- The Tingmerkpuk project team, led by Gil Mull and Ellen Harris, working in the foothills of the western Brooks Range, found exposures of organic-rich rocks along a 50 mile trend that are within the thermal regime of the "oil window." These rocks are considered to be excellent source rocks capable of generating both oil and gas, and may have significant implications for the oil and gas potential of the western part of the North Slope, including western National Petroleum Reserve, Alaska (NPRA). Elsewhere in the southern part of the foothill belt, newly documented structural relationships suggest a new class of exploration plays associated with potential reservoir rocks in southern NPRA. The project has received significant operational funding from the oil and gas industry, the Arctic Slope Regional Corporation, and the U.S. Geological Survey.

- John Reeder, who oversees the operation of the Division's Alaska Geologic Materials Center at Eagle River, reports that work is underway for the USBLM-sponsored upgrade of that facility. In addition to an improvement in the office facilities, material storage will be expanded by at least 70,000 cubic feet and the GMC materials database will be made accessible on the Internet.

- Chris Nye, working with the Alaska Volcano Observatory, reported that now almost half of Alaska's explosive volcanoes have been equipped with monitoring seismometers that will help predict imminent eruptions.

- As a final item, Rod Combellick's recent work on earthquake recurrence rates in the Cook Inlet region resulted in an international collaboration to investigate evidence of precursor changes that may result in the ability to forecast subduction-related earthquakes. Rod's colleagues will present this work at a U.N.-sponsored sea-level conference in Greece in September and at the Geological Society of America meeting in Toronto in October.

Sincerely,

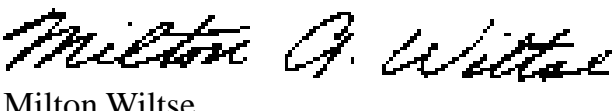

Milton Wiltse

Director and State Geologist

\section{Visit our web page at http://wwwdggs.dnr.state.ak.us}




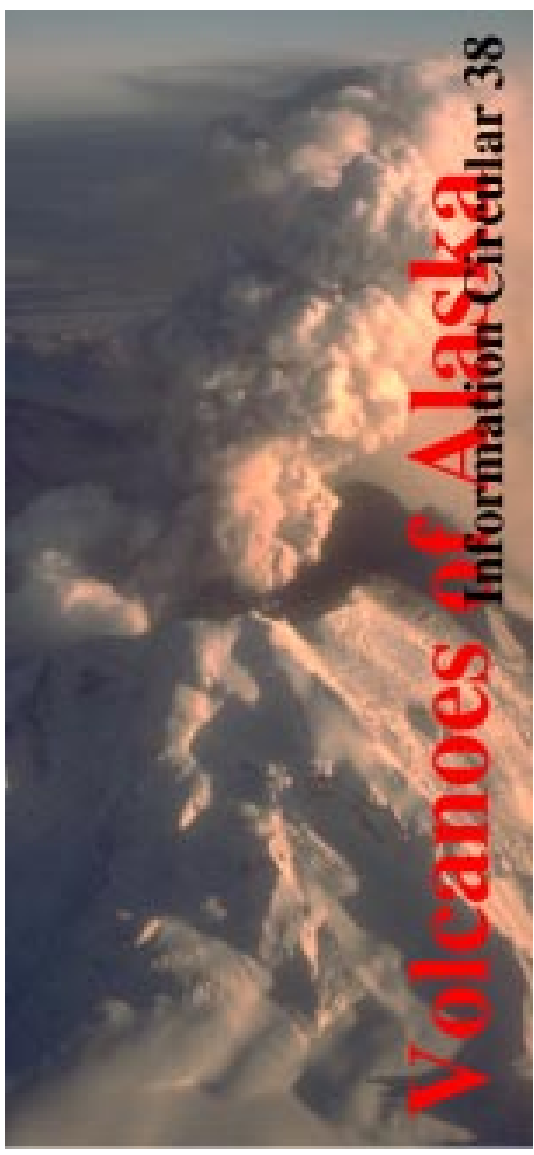

Information Circular 38, the popular brochure first released by the Alaska Volcano Observatory in 1995, has been revised and updated for a 1998 re-release. The colorful, two-sided poster has been given a new, slightly larger page size to accommodate expanded text and enlarged figures. AVO's revision of IC 38 was in response to the amazing amount of positive public feedback received after the first release of the brochure. The new IC 38 includes updated information on recent volcanic eruptions, monitoring procedures, and other topics unique to Alaska volcanism.

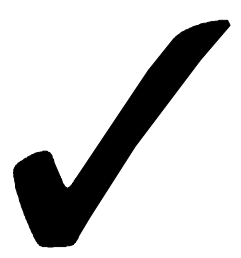

\section{Check it out}

- Alaska's Mineral Industry 1997 (Special Report 52), the latest in a series of annual reports detailing the state of the minerals industry in Alaska, is now available.

- The 1999 DGGS calendar, featuring a spectacular view of the Clearwater Mountains in the Alaska Range, will be available in November.

Stop by our office, email (dggspubs@dnr.state.ak.us), or call 451-5020 to get your copy.

Please send address corrections to:

Newsletter, Alaska Division of Geological \& Geophysical Surveys

794 University Ave., Suite 200, Fairbanks, AK 99709-3645

fax (907)451-5050

email: joni@dnr.state.ak.us

http://wwwdggs.dnr.state.ak.us 


\section{STATE OF ALASKA \\ DEPARTMENT OF NATURAL RESOURCES \\ DIVISION OF GEOLOGICAL \& GEOPHYSICAL SURVEYS}

Mail order to:

Division of Geological \& Geophysical Surveys

Attn: Geologic Communications Section

794 University Avenue, Suite 200

Fairbanks, Alaska 99709-3645

E-maildggspubs@dnr.state.ak.us http://wwwdggs.dnr.state.ak.us

Phone: (907) 451-5020

Fax: (907) 451-5050

\begin{tabular}{|c|c|c|c|c|c|}
\hline REPORT NO. & Title & QUANTITY & $\begin{array}{c}\text { UNIT } \\
\text { PRICE }\end{array}$ & Postage & Total \\
\hline & & & & & \\
\hline & & & & & \\
\hline & & & & & \\
\hline & & & & & \\
\hline & & & & & \\
\hline & & & & & \\
\hline & & & & & \\
\hline & & \multicolumn{3}{|c|}{ Total amount due } & \\
\hline
\end{tabular}

Domestic postage $\$ 1.00$ per copy of each report ordered Canada and Mexico, \$1.50 per copy of each report ordered All other international, $\$ 2.50$ surface, $\$ 5.00$ air mail per copy of each report ordered

\section{Ship publication(s) to:}

Name

Organization

Address

City, State Zip 
RI 98-14. Total field magnetics of the Holitna Basin area, western Alaska, by DGGS, On-Line Exploration Inc., and SIAL Inc. Staff, 2 sheets, scale 1:125,000. Full color plot from electronic file, 600 dpi. Made on request. \$26.

PR 104. Geologic map of the Chandalar C-5 Quadrangle, southeastern Brooks Range, Alaska, by J.T. Dillon, R.R. Reifenstuhl, and G.W. Harris, 1996, 2 sheets, scale 1:63,360. \$7.

PR 118. Short notes on Alaska geology 1997, by J.G. Clough and Frank Larson, eds., 1998, 142 p. \$9.

a. Geochronologic investigations of magmatism and metamorphism within the Kigluaik Mountains gneiss dome, Seward Peninsula, Alaska, by Jeffrey M. Amato and James E. Wright, $21 \mathrm{p}$.

b. Composite standard correlation of the Mississippian-Pennsylvanian (Carboniferous) Lisburne Group from Prudhoe Bay to the eastern Arctic National Wildlife Refuge, North Slope, Alaska, by John F. Baesemann, Paul L. Brenckle, and Paul D. Gruzlovic, $14 \mathrm{p}$.

c. Enigmatic source of oil from Chukchi Sea, northwestern Alaska, by Arthur C. Banet and Thomas C. Mowatt, $15 \mathrm{p}$.

d. Emsian (late Early Devonian) fossils indicate a Siberian origin for the Farewell Terrane, by Robert B. Blodgett, 9 p.

e. Growth-position petrified trees overlying thick Nanushuk Group coal, Lili Creek, Lookout Ridge Quadrangle, North Slope, Alaska, by Paul L. Decker, Gregory C. Wilson, Arthur B. Watts, and David Work, 8 p.

f. Paleotopographic control on deposition of the lower Kayak Shale, northern Franklin Mountains, Brooks Range, Alaska, by David L. LePain, 15 p.

g. Cooling history of the Okpilak batholith, northeastern Brooks Range, as determined from potassium-feldspar thermochronometry, by Julie S. Paegle, Paul W. Layer, and Andrew W. West, 11 p.

h. First occurrence of a hadrosaur (Dinosauria) from the Matanuska Formation (Turonian) in the Talkeetna Mountains of south-central Alaska, by Anne D. Pasch and Kevin C. May, 11 p.

\section{ORDERING INFORMATION}

For each publication ordered, include both the publication title and number. Mail orders are payable in advance. Make check or money order in U.S. currency and payable to the State of Alaska. Credit cards are not accepted. Telephone orders are accepted by the Fairbanks office between 8 a.m. and 5 p.m. Alaska time. Fax and email requests are accepted any time; these orders will be invoiced. If you would like to leave your order on voice mail, this can also be done 24 hours a day and you will be invoiced.

\section{SHIPPING \& HANDLING}

-Domestic postage - \$1.00/copy of each report

-Canada and Mexico - \$1.50/copy of each report

-All other international - \$2.50 surface

$\$ 5.00$ air/copy of each report

-For rolled-map orders requiring mailing tubes, add an additional $\$ 3.50$.

\section{WHERE TO ORDER}

Publications of the Division of Geological \& Geophysical Surveys are available over the counter, by mail, phone, fax, or email from the DGGS Fairbanks office:

ATTN: Geologic Communications Section-Sales Alaska Division of Geological \& Geophysical Surveys, 794 University Avenue, Suite 200 Fairbanks, AK 99709-3645

(907) 451-5020 Fax (907) 451-5050

Email:dggspubs@dnr.state.ak.us

Prices of DGGS publications are subject to change. Increases in costs make it necessary to raise the selling prices of many publications offered. It is not feasible for DGGS to change the prices stated in previous announcements and publications in stock, so the prices charged may differ from the prices in the announcements and publications. Overpayments of $\$ 2$ or less will not be refunded. 


\section{PUBLICATIONS}

i. Petrography of the Tingmerkpuk Sandstone (Neocomian), northwestern Brooks Range, Alaska: A preliminary study, by Rocky R. Reifenstuhl, Michael D. Wilson, and Charles G. Mull, 14 p.

j. Lower to Middle Devonian (latest Emsian to earliest Eifelian) conodonts from the Alexander Terrane, southeastern Alaska, by Norman M. Savage and Constance M. Soja, 5 p.

k. Preliminary petrography and provenance of six Lower Cretaceous sandstones, northwestern Brooks Range, Alaska, by Marwan A. Wartes and Rocky R. Reifenstuhl, $10 \mathrm{p}$.

SR 52. Alaska's mineral industry 1997, by R.C. Swainbank, K.H. Clautice, and J.L. Nauman, 1998, 65 p. Free.

Public-Data Files (PDF) are unpublished documents that make project data immediately available to the public. PDFs usually comprise raw data and have not undergone peer review or been edited by DGGS staff. In many cases, PDFs are later released as DGGS Reports of Investigations (RI), Special Reports (SR), or Professional Reports (PR). Prices for PDFs are determined by their individual reproduction prices and are thus sold at copying costs. Information Circulars (IC) are normally free.

PDF 98-25. Project report of the airborne geophysical survey for the northeastern portion of the Koyukuk mining district, eastern Brooks Range, Alaska, by DGGS, On-Line Exploration Inc., and SIAL Inc. Staff, July 1998, 144 p., 2 sheets, scale 1:63,360. \$27.

PDF 98-27. Total field magnetics and flight line paths of the Holitna Basin area, western Alaska, by DGGS, On-Line Exploration Inc., and SIAL Inc. Staff, May 1998, 4 sheets, scale 1:125,000. $\$ 12$.

PDF 98-29. Project report of the aeromagnetic survey for the Holitna Basin area, western Alaska, by DGGS, On-Line Exploration Inc., and SIAL Inc. Staff, August 1998, 82 p., 2 sheets, scale 1:125,000. \$23.70.

PDF 98-36a. Preliminary geochemical and major oxide data: 1997 Chulitna project, Healy A-6 Quadrangle and nearby areas, by B.G. Gage, P.S. Chu, S.A. Liss, and K.H. Clautice, March 1998, 1 disk. \$5.

PDF 98-37a. Geologic map of the Tanana A-1 and A-2 quadrangles, central Alaska, by R.R. Reifenstuhl, J.H. Dover, R.J. Newberry, K.H. Clautice, D.S. Pinney, S.A. Liss, R.B. Blodgett, and F.R. Weber, May 1998, 19 p., 1 sheet, scale 1:63,360. \$15.

PDF 98-37b. Interpretive geologic bedrock map of the Tanana A-1 and A-2 quadrangles, central Alaska, by R.R. Reifenstuhl, J.H. Dover, R.J. Newberry, K.H. Clautice, S.A. Liss, R.B. Blodgett, and F.R. Weber, May 1998, 17 p., 1 sheet, scale 1:63,360. \$14.

PDF 98-37c. Surficial geologic map of the Tanana A-1 and A-2 quadrangles, central Alaska, by D.S. Pinney, May 1998, 1 sheet, scale 1:63,360. \$13.

PDF 98-37d. Derivative engineering geologic map of the Tanana A-1 and A-2 quadrangles, central Alaska, by D.S. Pinney, May 1998, 1 sheet, scale 1:63,360. \$14.

PDF 98-38. Cretaceous and Jurassic megafossil collections, 1994-1996, Tingmerkpuk project, northwest DeLong Mountains, western Arctic Slope, Alaska, by W.P. Elder, May 1998, 9 p., 1 sheet, scale 1:250,000. $\$ 9.50$.

PDF 98-41. Hydrologic data for the Matanuska River watershed, southcentral Alaska, by M.A. Maurer, July 1998, 16 p. \$2. 